\title{
REVIEW
}

\section{Coffee bacterial diseases: a plethora of scientific opportunities}

\author{
J. L. Badel ${ }^{\mathrm{a*}}(\mathrm{D})$ and L. Zambolim ${ }^{\mathrm{b}}$

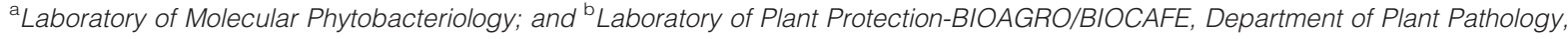 \\ Universidade Federal de Viçosa, Ave. P. H. Rolfs s/n, Viçosa, 36570-900, MG, Brazil
}

Coffee is a very important crop for several tropical countries across different continents. The diseases bacterial halo blight (BHB), bacterial leaf spot (BLS), bacterial leaf blight (BLB) and coffee leaf scorch (CLS), caused by the bacterial pathogens Pseudomonas syringae pv. garcae (Psgc), P. syringae pv. tabaci (Psta), Pseudomonas cichorii (Pch) and Xylella fastidiosa subsp. pauca (Xfp), respectively, cause significant reductions in coffee production, although other minor bacterial diseases have also been reported in some countries. Little research progress has been made on aspects that are relevant for control and management of these diseases. In all cases, there is an urgent need to develop rapid and more reliable methods for early detection of the pathogens in order to minimize their negative impact on coffee production. Because of the high rate of intra- and intersubspecific recombination occurring in X. fastidiosa, a permanent revision of the detection methods is necessary. Greater efforts should be made to understand the genetic and virulence diversity of Psgc, Psta and Pch populations. Early studies reported the identification of potential sources of resistance against Psgc and Psta, but, to date, no resistance gene has been isolated. Little effort has been made to understand the biology and molecular mechanisms underlying the interaction between Coffea spp. and these pathogenic bacteria. This review discusses the recent progress on the molecular mechanisms used by these bacteria to cause diseases on other plant species, in order to provide a guideline for the establishment of future research programmes.

Keywords: bacterial blight, Coffea, leaf scorch, pathogen detection, Pseudomonas syringae, Xylella fastidiosa

\section{Introduction}

Coffee (Coffea spp.) is a very important commodity for a number of tropical countries in South America, Central America, Asia and Africa. It plays an important socioeconomic role contributing to employment and settlement of families in production areas. Coffee production in several countries is threatened by abiotic and biotic stresses, including diseases caused by phytopathogenic bacteria. The four bacterial species Robbsia andropogonis (synonym Burkholderia andropogonis) (Rodrigues Neto et al., 1981), Pseudomonas syringae (Franco Do Amaral et al., 1958; Ramos \& Shavdia, 1976; Rodrigues et al., 2006, 2017c; Destéfano et al., 2010), Pseudomonas cichorii (Robbs et al., 1974; Almeida et al., 2012b) and Xylella fastidiosa (Paradela Filho et al., 1997; Lima et al., 1998) have been reported to cause disease on coffee plants under field conditions. Within $P$. syringae, pathovars garcae (Amaral et al., 1956; Ramos

*E-mail: jorge.badel@ufv.br

Published online 8 January 2019
\& Shavdia, 1976; Korobko \& Wondinagegne, 1997; Chen, 2002; Bai et al., 2013), tabaci (Rodrigues et al., 2006, 2017c; Destéfano et al., 2010) and syringae (Franco Do Amaral et al., 1958; Baker, 1972; Ramos \& Shavdia, 1976; Okioga, 1977; Cortés Monllor, 1988) have been associated with similar disease symptoms.

Despite the considerable damage these bacteria cause on coffee, a crop of high socioeconomic importance, neither efficient methods for their reliable detection nor their efficient control are currently available. Also, little is known about the biology of the interaction of these bacterial species with coffee plants. This review discusses the relevant aspects of coffee diseases caused by these bacterial pathogens and brings together information on their pathogenicity mechanisms that could be used as guidelines for establishing research programmes aimed to better understand the biology of the interactions and to develop effective alternatives for disease management and control. Herein, the current methods used to control these diseases will not be discussed, because they mostly rely on the implementation of preventive measures such as planting certified seedlings, avoiding pathogen entry in the area by planting natural windbreaks and avoiding injuries on the leaves and branches by mechanical 
implements. Chemical treatment in areas with history of the disease usually involves preventive application of copper-based compounds alone or in mixtures with mancozeb (and insecticides in the case of X. fastidiosa) sometimes in alternation with kasugamycin (Zambolim et al., 2005; Patrício et al., 2010; Patrício \& Oliveira, 2014). In the case of $X$. fastidiosa, severe pruning has also been proposed as an efficient alternative to control the disease (Queiroz-Voltan et al., 2006; Rocha et al., 2010b).

\section{Bacterial halo blight}

\section{Disease symptoms, aetiology and dissemination}

Pseudomonas syringae pv. garcae (Psgc), the causal agent of bacterial halo blight (BHB) of coffee, was first described in 1955 by Amaral et al. (1956) in the municipality of Garça in the Brazilian state of São Paulo. It was also reported in the states of Paraná (Mohan et al., 1978) and Minas Gerais (Kimura et al., 1973; Zoccoli et al., 2011) in Brazil. Bacterial halo blight has been reported in Kenya (Ramos \& Shavdia, 1976), Ethiopia (Korobko \& Wondinagegne, 1997), Uganda (Chen, 2002) and China (Chen, 2002; Bai et al., 2013). Although the disease was initially considered of minor importance, recurrent outbreaks have occurred in coffee plantations in several Brazilian states, mainly at higher altitudes (Kimura et al., 1973; Mohan, 1976; Cafepoint, 2011; Zoccoli et al., 2011; Rodrigues et al., 2013).

Characteristic symptoms of the disease include the formation of necrotic spots surrounded or not by chlorotic haloes (Fig. 1a). The lesions are more evident on the leaf borders, but flowers, fruits and branches can also be affected. Under severe infection, the disease can cause blackening of twigs and blighting of branch tips, resulting in dieback, defoliation, and apical meristem death, which in turn induces over-branching (Fig. 1b,c) (Zambolim et al., 1999, 2005; Rodrigues et al., 2013). Disease development is favoured by mild temperatures, high wind intensity and rain, especially hail stone rain, which produces injuries that facilitate bacterial penetration (Rodrigues et al., 2013). High increases in disease incidence have occurred after frost, for example after the 1973-1975 period in the state of Paraná (Kimura et al., 1973; Mohan, 1976), which could be facilitated by the ice-nucleation activity exhibited by Psgc (Gonçalves \& Massambani, 2011; Araújo et al., 2018).

It has been estimated that $\mathrm{BHB}$ can cause losses of up to $70 \%$ in nurseries and in the field, predominantly in regions above $1000 \mathrm{~m}$ a.s.l. in the presence of severe wind (Zoccoli et al., 2011). The bacterium survives mainly as an epiphyte and associated with plant debris. It penetrates the host tissue through natural openings (stomata) or wounds and is mainly disseminated by water and wind-driven aerosol particles (Zoccoli et al., 2011). A recent study suggests that coffee seed may also be a source of inoculum (Belan et al., 2016).

\section{Plant genetic resistance}

Early studies on the resistance to Psgc indicated that Ethiopian C. arabica cultivars Hara, Dilla and Alghe, S12 and Geisha were resistant to the bacterium, which was attributed to the SH1 gene that also confers resistance to some races of the rust fungus Hemileia vastatrix (Moraes et al., 1974; Petek et al., 2006). Additional potential sources of resistance to BHB were identified in some varieties of C. arabica, some genotypes derived from Caturra $\times$ Timor hybrids, and the species Coffea eugenioides and Coffea stenophylla (Mohan et al., 1978). The existence of genes that confer resistance to $\mathrm{BHB}$, in addition to $S H 1$, is supported by results obtained with progenies derived from crosses of Caturra with the Timor hybrid (Mohan et al., 1978; Cardoso \& Sera, 1983), IAPAR-59 with descendants of C. arabica SH1 × Catuaí Vermelho IAC 81 (Petek et al., 2001, 2006), and Catuaí Vermelho IAC 24 with IAC 1137-5 of Geisha (Rodrigues et al., 2017b).

In Brazil, in studies conducted in the state of Paraná, C. arabica IPR 102 was found to be completely resistant under natural field infections whereas other cultivars, such as IPR 103, IPR 104, IPR 108 and IPR 59 exhibited incomplete resistance (Ito et al., 2005, 2008). Petek et al. (2001, 2006) reported that IAPAR-59 was a source of potentially important resistance in the state of Paraná. In contrast, Zoccoli et al. (2011) did not observe high levels of resistance when IAPAR-59 was inoculated with a strain from Carmo do Paranaíba, Minas Gerais state. It is probable that virulence variations between bacterial strains may be responsible for the observed differences. Such a possibility was suggested by Petek et al. (2006) when progenies of Catuaí $\times$ Icatú PRFB 2-27-1 did not exhibit the same level of resistance that was observed in previous studies (Kairu, 1997). In Ethiopia in field surveys conducted by Hinkosa et al. (2016, 2017), differences in disease severity and incidence were observed between the Sidama and southwestern zones. In most studies reported to date, the majority of coffee genotypes exhibited disease symptoms although at different levels, meaning that a classical gene-for-gene interaction was not clearly detected. However, in some studies, such as those conducted by Mohan et al. (1978) and Petek et al. (2006), Coffea genotypes that exhibited immunity to the disease were found, suggesting potential sources of major gene resistances. However, no reports on the identification of the resistance genes have been published so far.

One of the major difficulties when trying to establish comparisons among different studies is that several inoculation methods have been used to evaluate plant resistance. In some studies, leaves were previously wounded using different techniques (Ithiru et al., 2013; Rodrigues et al., 2017a; Maciel et al., 2018); in others they were not wounded (Rodrigues et al., 2017a). Some of those studies have shown that the reactions of the coffee genotypes were highly dependent on the inoculation method and that some methods seem to be better in discriminating differences in resistance to the pathogen (Ithiru et al., 

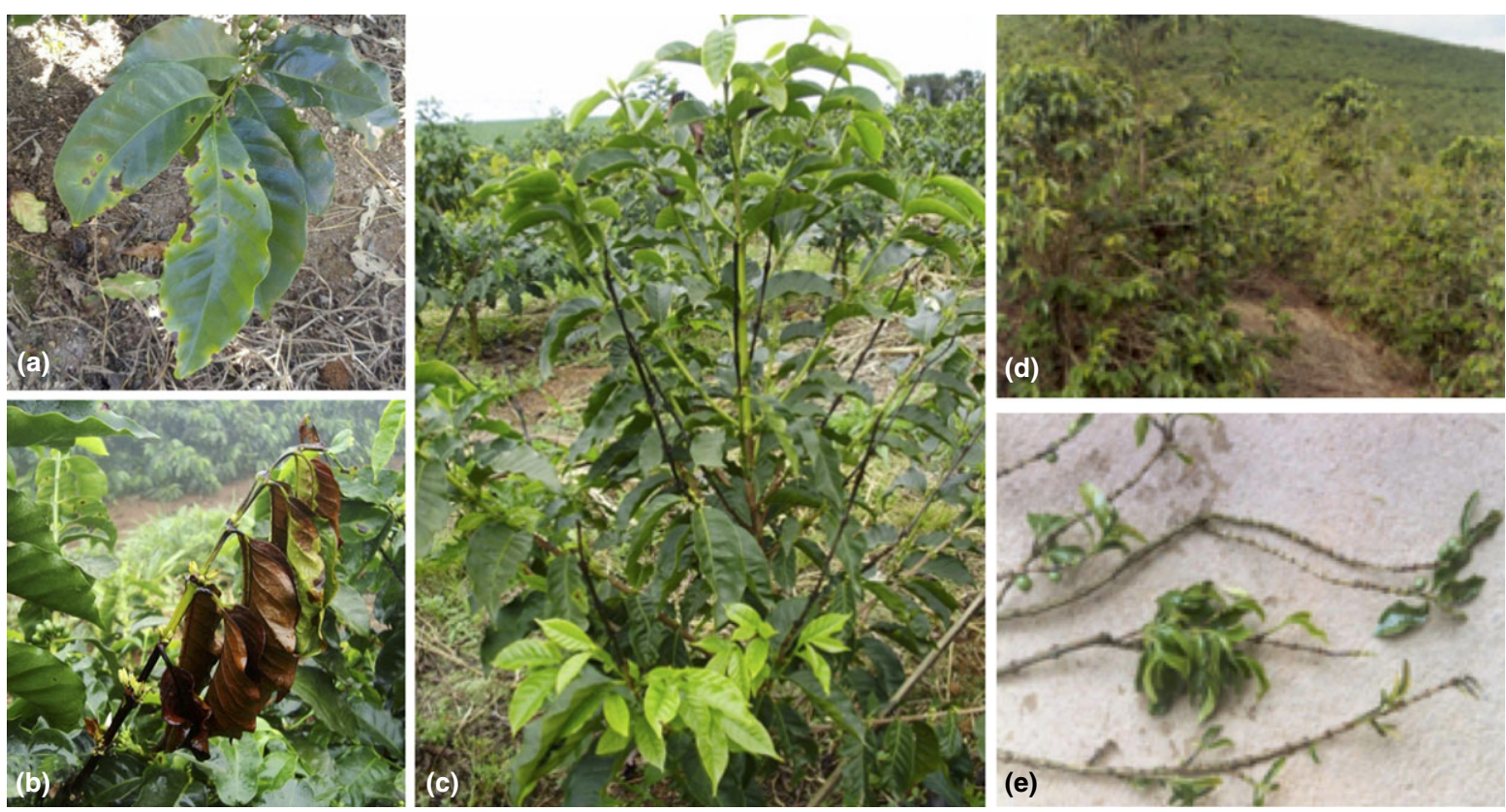

Figure 1 Symptoms of coffee bacterial diseases. (a) Foliar necrotic spots surrounded by chlorotic haloes, (b) death of branches and apical meristem, and (c) stem necrosis and plant defoliation caused by Pseudomonas syringae pv. garcae. (d) Leaf chlorosis and plant defoliation and (e) internode shortening and defoliation caused by Xylella fastidiosa subsp. pauca. Photos courtesy Rui P. Leite Jr, Instituto Agronômico do Paraná (a, b), Flávia R. A. Patrício, Instituto Agronômico de Campinas (c), and Laércio Zambolim, Universidade Federal de Viçosa (d, e). [Colour figure can be viewed at wileyonlinelibrary.com]

2013; Rodrigues et al., 2017a). Therefore, there is an urgent need to establish standardized methods for plant resistance evaluation. More importantly, the aggressiveness (and possible virulence) variability of the pathogen population should be taken into consideration when selecting resistant genotypes.

\section{Taxonomy, host range and genetic diversity}

Pseudomonas syringae pv. garcae is a rod-shaped, strictly aerobic, fluorescent, Gram-negative bacterium that belongs to the family Pseudomonadaceae, order Pseudomonadales of the Gammaproteobacteria. It clusters in genomospecies 4 based on DNA-DNA hydridization (Gardan et al., 1999) and rpoD-based phylogenetic analysis (Parkinson et al., 2011; Raimundi, 2017), along with informal nomospecies Pseudomonas coronafaciens. Hence, Psgc has lately been referred to as $P$. coronafaciens pv. garcae.

Although it is well known that the species $P$. syringae is highly variable, the genetic variability of Psgc has been poorly investigated. Early studies demonstrated biochemical and genetic variability at the intrapathovar level. For instance, Kairu (1997) reported that Brazilian and Kenyan strains differed with regard to production of bacteriocins and fluorescent pigments. Mwangi et al. (2018) reported variability in the $16 \mathrm{~S}$ rDNA sequence and found that the most aggressive strains clustered together in the phylogenetic tree, but no correlation with geographic origin was observed. In contrast, Maciel et al. (2018) when using rep-PCR to evaluate the genetic diversity of
Brazilian and Kenyan strains, found clustering according to geographic origin, although no clear correlation with aggressiveness was detected. A major caveat of those studies is that a small number of strains was evaluated and it is difficult to draw clear conclusions. Studies using larger populations, from different geographic areas, are needed in order to gain a better understanding of the genetic diversity and population structure of the phytopathogen.

Aggressiveness variation among Psgc strains is supported by studies conducted in Kenya and Brazil (Ithiru et al., 2013; Rodrigues et al., 2017a; Maciel et al., 2018; Mwangi et al., 2018). Interestingly, Kairu (1997) found that cultivar SL 28 was resistant to Brazilian strains but susceptible to Kenyan strains, suggesting a possible virulence variability among bacterial populations. Also, a possible geographic adaptation of Psgc to infect additional plant species is suggested by a study indicating that strains from Kenya can also cause disease on oat plants (at least under experimental conditions) whereas those from Brazil cannot. It is not clear whether this specialization is at the host species or cultivar level, because only one oat cultivar was used in the experiments (Barta $\&$ Willis, 2005). These results suggest the possibility that some bacterial genes could restrict the host range of some Psge populations to additional hosts. Furthermore, although that study was conducted with only a few strains from each country, its results suggest that genes that confer resistance to coffee bacterial blight could be procured in distantly related plant species, including monocots. 


\section{Pathogen detection}

Molecular and serological methods for specific detection of Psgc in infected tissue have not been reported. Current methods rely on isolation and identification of the bacterium using morphological, physiological and biochemical tests (Zoccoli et al., 2011; Belan et al., 2016; Hinkosa et al., 2016; Rodrigues et al., 2017c). Distinction between Psgc and other P. syringae pathovars is commonly achieved by LOPAT testing (Rodrigues et al., 2017c). Pseudomonas syringae pv. garcae can be differentiated from P. syringae pv. tabaci and P. syringae pv. syringae by assaying for production of pectate lyase and utilization of L-trigonelline, $\mathrm{L}-(+)$-tartrate and lactate (Young \& Triggs, 1994). At the present time, specific identification using molecular methods has been attempted only using rep-PCR (Kairu, 1997; Belan et al., 2016). The availability of the genome sequence of Psgc strain ICMP 4323 (Thakur et al., 2016) could help identify pathovar-specific DNA regions useful for development of PCR-based and serological detection methods.

\section{Mechanisms of pathogenicity}

Studies on the mechanisms by which Psgc causes disease on coffee plants have not been reported. Like many other phytopathogenic pseudomonads, Psgc possesses genes coding for a type III secretion system (T3SS), considered a major pathogenicity determinant of this taxonomic group. The T3SS is coded by hrp/hrc genes that are widely conserved in species of the genera Xanthomonas, Pseudomonas, Ralstonia, Erwinia and Pantoea (Collmer et al., 2000). The presence of such a secretion system as well as of its cargo proteins was verified in the genome sequence of Psgc ICMP 4323 (Thakur et al., 2016). Furthermore, it was also demonstrated that Psgc 1202 carries a functional T3SS able to translocate chimeric fusions of adenylate cyclase (CyaA) or H. vastatrix effectors with $\mathrm{N}$-terminal secretion signals of bacterial T3SS effectors into the cytoplasm of C. arabica cells (Maia et al., 2016). Nonetheless, the importance of the T3SS for the pathogenicity of Psgc remains to be investigated.

Pseudomonas syringae pathovars also deliver phytotoxins that contribute to symptom development during the interaction with their hosts. It has long been demonstrated that Psgc produces the monocyclic $\beta$-lactam tabtoxin that has been associated with the formation of chlorotic haloes (Bender et al., 1999). Consistently, some Psgc strains that do not cause chlorotic haloes have been shown not to produce tabtoxin (Barta \& Willis, 2005). Tabtoxin is cleaved by a plant amino peptidase releasing tabtoxinine- $\beta$-lactam, which causes inhibition of glutamine synthase (Bender et al., 1999).

\section{Bacterial leaf spot}

\section{Disease symptoms, aetiology and dissemination}

Bacterial leaf spot (BLS) was first reported by Rodrigues et al. (2006) in coffee nurseries in São Paulo state. This disease has been reported only in Brazil (Rodrigues et al., 2006, 2017c; Destéfano et al., 2010; Raimundi, 2017). In the state of São Paulo, BLS was associated with leaf spots on Catuaí plants in a commercial nursery located in Arandu at a disease incidence of $1-2 \%$. Symptoms appeared initially in the leaves as small brown lesions that turned into black and angular spots (Destéfano et al., 2010). More recently, the aetiologic agent was also detected in plant samples collected in several localities in the states of Paraná and Minas Gerais (Raimundi, 2017). Pseudomonas syringae pv. tabaci (Psta) was found to be sympatric and causing mixed infections with Psgc (Rodrigues et al., 2017c). Because symptoms of BLS highly resemble those of $\mathrm{BHB}$, and differentiation between the two $P$. syringae pathovars causing them using biochemical methods is sometimes difficult, it is probable that the importance of the disease in Brazil has been underestimated. As a consequence, studies on the epidemiology, survival and dissemination of the pathogen are scarce. The sympatric and mixed infection occurring between Psta and Psgc could provide an explanation for why some coffee genotypes that exhibited high levels of resistance to Psgc (Petek et al., 2001, 2006) showed more severe disease symptoms when tested in subsequent studies (Zoccoli et al., 2011).

\section{Plant genetic resistance}

Studies on the identification of resistance against Psta in coffee germplasm have not been reported. The types of resistance (quantitative or qualitative) that act in coffee against the bacterial pathogen remain unknown. Sources of resistance against Psta have been identified in several Nicotiana species (Burk \& Heggestad, 1966; Stavely, 1979; Goy et al., 1992). Some of the resistance genes have been transferred to cultivated Nicotiana tabacum via interspecific hybridization (Clayton, 1947; Smeeton \& Ternouth, 1992; Woodend \& Mudzengerere, 1992). Soybean cultivars resistant to Psta have also been obtained (Rose, 1989; Carnielli et al., 1992). These results suggest the possibility of developing coffee cultivars resistant to Psta using genes identified in other host plant species. Nonetheless, there are no recent reports on the identification of new sources of resistance and development of resistant cultivars. Consequently, the effectiveness of genes identified in early studies should be verified, because strains that overcome plant resistance have been reported (Valleau et al., 1962).

Alternatives to endogenous resistance for the control of Psta have also been explored. Enhanced resistance has been obtained by cisgenic overexpression and by expression of genes from other plant species, insects, bacteria and even coding for synthetic peptides in the model plant N. tabacum (Table 1). Whether these genes enhance resistance to Psta in coffee plants remains to be investigated and they are candidates for development of coffee resistant varieties. Importantly, because Psta strains that produce tabtoxin also possess a cognate tabtoxin resistance gene $(t t r)$ for detoxification, the $t t r$ genes can 
Table 1 Genes that have been shown to confer enhanced resistance against Pseudomonas syringae pv. tabaci.

\begin{tabular}{|c|c|c|c|}
\hline Gene & Function & Source & Reference \\
\hline PAO & Polyamine oxidase & Tobacco (Nicotiana tabacum) & Moschou et al. (2009) \\
\hline OPBP1 & $\begin{array}{l}\text { Osmotin promoter-binding } \\
\text { protein }\end{array}$ & Tobacco (N. tabacum) & Guo et al. (2004) \\
\hline OsDRF1 & F-box protein & Rice (Oryza sativa) & Cao et al. (2008) \\
\hline OsBIRF1 & RING finger protein & Rice (O. sativa) & Liu et al. (2008) \\
\hline OSLOL2 & $\begin{array}{l}\text { Arabidopsis LSD1 (zinc finger } \\
\text { protein) orthologue }\end{array}$ & Rice (O. sativa) & Bhatti et al. (2008) \\
\hline$\alpha$-thionin & Cystein-rich peptide & Barley (Hordeum vulgare) & Carmona et al. (1993) \\
\hline VVPR1b & $\begin{array}{l}\text { Pathogenesis-related } \\
\text { protein } 1\end{array}$ & $\begin{array}{l}\text { Interspecific grapevine (Vitis) } \\
\text { hybrid BN5-4 }\end{array}$ & Li et al. (2011) \\
\hline pflp & Ferredoxin-like protein & Sweet pepper (Capsicum annuum) & Huang et al. (2004) \\
\hline LTP & Lipid transfer protein & Pepper (C. annuum) cv. Bugang & Sarowar et al. (2009) \\
\hline HRAP & $\begin{array}{l}\text { Hypersensitive } \\
\text { response-assisting protein }\end{array}$ & Sweet pepper (C. annuum) & Ger et al. (2003) \\
\hline Sarcotoxin IA & Bactericidal peptide & Flesh fly (Sarcophaga peregrina) & Ohshima et al. (1999), Mitsuhara et al. (2000) \\
\hline ipt & Isopentenyl transferase & Agrobacterium tumefaciens & Großkinsky et al. (2011) \\
\hline ttr & Tabtoxin resistance & Pseudomonas syringae pv. tabaci & Anzai et al. (1989), Batchvarova et al. (1998) \\
\hline MB39 & Cecropin-like lytic peptide & Synthetic lytic peptide & Huang et al. (1997) \\
\hline$D 2 A 21$ & Antimicrobial peptide (AMP) & Synthetic AMP & Hao et al. (2017) \\
\hline MSI-99 & $\begin{array}{l}\text { Analogue of magainin } 2 \\
\text { (African clawed frog, } \\
\text { Xenopus laevis) }\end{array}$ & Synthetic AMP & DeGray et al. (2001) \\
\hline
\end{tabular}

potentially be used to create plants resistant to the toxin. Using such a rationale, Anzai et al. (1989) and Batchvarova et al. (1998) demonstrated that constitutive expression of the $t$ tr gene from Psta in several cultivars of N. tabacum conferred enhanced resistance to the pathogen. Because many strains of both Psta and Psgc produce tabtoxin, this approach could be effective to control both pathogens. Reports of studies using ttr under the control of tissue-specific promoters in coffee plants have not been reported.

Another alternative to control Psta is the induction of plant resistance. Exogenous application of theobroxide, a natural epoxy cyclohexene produced by strain OCS71 of Lasiodiplodia theobromae, caused restriction of Psta growth and reduction in symptom development in Nicotiana benthamiana (Ahn et al., 2013). Application of acibenzolar-S-methyl, an inducer of systemic acquired resistance (Cole, 1999), and of pyraclostrobilurin, a strobilurin fungicide (Herms et al., 2002) to N. tabacum have been shown to induce resistance against Psta.

\section{Pathogen detection}

As for other Pseudomonas that infect coffee, detection of Psta is currently based on morphological, physiological and biochemical tests. Even though Psgc, Psta and Pseudomonas cichorii (Pch) can be clearly distinguished using rpoD-based phylogenetic analysis after a somewhat long and cumbersome process that requires well-trained laboratory personnel (Parkinson et al., 2011; Raimundi, 2017), practical methods for detection must be developed. Attempts to develop simple detection methods based on the polymorphisms present in the $r p o D$ locus have not been reported. Detection methods could also be based on initial comparisons of the genomes of strains that belong to the three coffee pathogens that are available in the databases to identify DNA regions or biochemical functions specific to each one of them. The establishment of such methods could help determine the real impact of the disease in coffee plantations.

\section{Taxonomy, host range and genetic diversity}

Pseudomonas syringae pv. tabaci is morphologically very similar to Psgc and was traditionally classified in the same suprapathovar taxonomic groups. However, Psta clusters in genomospecies 2 ('amygdali' group) based on DNA-DNA hybridization (Gardan et al., 1999) and rpoD-based phylogenetic analysis (Parkinson et al., 2011; Raimundi, 2017). Because the nomospecies Pseudomonas amydali was already validly published, Psta has lately been referred to as Pseudomonas amygdali pv. tabaci.

Studies on the genetic diversity of Psta associated with coffee have not been reported in peer-reviewed articles and little is known about the genetic structure of populations associated with other host plants. Results from a single study suggest that the population of Psta has a high genetic diversity (Peng et al., 2003). Nonetheless, understanding of the pathogen population associated with coffee should be furthered. This $P$. syringae pathovar is widely distributed in all continents and has a wide host range, comprising species of several different botanical families (Bradbury, 1986; Tanaka et al., 1993; 
Beriam et al., 2006; Malavolta Júnior et al., 2008; CABI, 2018). The specificity of strains toward a particular host is largely unknown. In a recent study, Raimundi (2017) found that strains from N. tabacum, Phaseolus vulgaris, Cucumis sativus, Carica papaya, Desmodium canum, Celosia plumosa and Aster sp. were able to infect C. arabica 'Catuaí Vermelho IAC 99', causing symptoms in the greenhouse similar to those observed under natural conditions. These results suggest that other plant species (associated with coffee plantations) could serve as sources of inoculum in the field and that cross-infection could occur. However, this hypothesis must be proved by conducting field experiments.

With regard to the pathotypic composition of the bacterial population, early studies considered the existence of two races, 0 and 1 , the latter not being capable of causing disease on various Nicotiana species (N. nudicaulis, N. repanda, N. rustica and N. undulata; Stavely, 1979). However, the differential interaction of bacterial isolates with coffee cultivars and species remains largely unknown.

\section{Mechanisms of pathogenicity}

As for other phytopathogenic pseudomonads, the T3SS is a major pathogenicity determinant in Psta. In a genome comparison study, it was shown that Psta strain 11528 carries a $h r p / h r c$ region, containing a conserved effector locus (CEL) and an exchangeable effector locus (EEL) (Studholme et al., 2009), similar to the tripartite island previously identified in $P$. syringae pv. tomato (Pst) DC3000 (Alfano et al., 2000). In Psta 11528, the CEL is well conserved whereas the EEL is reduced compared to the Pst DC3000 EEL and contains only one effector (avrPphE) (Alfano et al., 2000; Deng et al., 2003). Fifteen of the Psta 11528 effectors are conserved in Pst DC3000, whereas only one effector (hopAE1) is conserved in $P$. syringae pv. phaseolicola $1448 \mathrm{a}$ and $P$. syringae pv. syringae $\mathrm{B} 728 \mathrm{a}$, two strains that cause disease on common bean ( $P$. vulgaris) (Studholme et al., 2009). Interestingly, Psta 11528 carries a truncated version of hopM1, which has been shown to play a key role in the pathogenicity of Pst DC3000 (Badel et al., 2003, 2006). However, Psta 11528 carries AvrE1, which is also a key determinant in the pathogenicity of Pst DC3000 (Badel et al., 2006). As expected, Psta 11528 does not carry a copy of hopQ1, a gene that confers avirulence toward $N$. benthamiana (Wei et al., 2007). It is worth mentioning that the T3SS effector complement varies according to the strain. Some effectors are present in some strains but not in others that belong to the same pathovar, as demonstrated for Pst strains DC3000 and T1 (Almeida et al., 2009). Effectors have been shown to suppress the plant defence response to contribute to virulence. For example, HopX1 from Psta 11528 is a cysteine protease that causes degradation of JAZ proteins (a family of proteins that repress jasmonic acid (JA)-responsive genes) to promote susceptibility in plants (Gimenez-Ibanez et al., 2014).
Psta produces tabtoxin, which has been associated with the formation of the chlorotic haloes that surround the necrotic lesions (Clayton, 1934; Anzai et al., 1990). The involvement of additional nonproteinaceous effectors was suggested recently by Lee et al. (2013). The authors reported that an extracellular, thermostable secondary metabolite produced by Psta suppresses several $N$. benthamiana defence responses against nonadapted bacterial pathogens, including stomatal closure and the hypersensitive response (HR). However, the nature of the metabolite and its involvement in suppression of plant defence responses during compatible interactions remain to be determined (Lee et al., 2013).

The ability of Psta to cause disease on its host plants is the result of the concerted action of several factors. In addition to tabtoxin and T3SS effectors, the assembly of type IV pili (T4P) (Taguchi \& Ichinose, 2011; Nguyen et al., 2012) and flagella (Ichinose et al., 2003; Taguchi et al., 2009) and the production of the siderophore pyoverdine (Taguchi et al., 2010) have also been shown to play important roles in the pathogenicity of Psta. Type IV pili are assembled through the general secretion pathway and a protein machinery that resembles the type II secretion system (T2SS) (Tanassi et al., 2012). Several of those factors, such as tabtoxin and siderophore production, T3SS assembly and T3SS effector gene expression are coordinately regulated by complex regulatory networks that include the GacS/GacA two-component quorum-sensing system (Marutani et al., 2008), AefR (a member of the TetR transcription factors; Kawakita et al., 2012; Yun et al., 2015), Fur (involved in iron acquisition; Cha et al., 2008, 2012) and the virulence factor regulator $\mathrm{Vfr}$ (a member of the $3^{\prime}, 5^{\prime}$-adenosine monophosphate (cAMP) receptor proteins; Taguchi \& Ichinose, 2013).

\section{Bacterial leaf blight}

\section{Disease symptoms, aetiology and dissemination}

Pseudomonas cichorii (Pch) has been reported in several Brazilian states causing bacterial leaf blight (BLB) on coffee plants (Robbs et al., 1974; Almeida et al., 2012b). The bacterium seems to establish epiphytic populations on the leaf surface and its penetration to the plant has been associated with injuries caused by fungi (Phoma and Cercospora) and by the coffee leaf miner Leucoptera coffeela (Robbs et al., 1974; Kimura et al., 1976). Although BLB mainly occurs in seedlings and reports in adult plants have treated the pathogen as an epiphyte, a recent study demonstrated that it can cause disease symptoms under field conditions in the state of Minas Gerais, Brazil (Raimundi, 2017). Pathogenic Pch isolates were also recovered from C. arabica nurseries in eight municipalities of Puerto Rico (Sánchez et al., 2003). It has been reported that BLB can cause the loss of between $64 \%$ and $85 \%$ of coffee plants in the nurseries (Sánchez et al., 2003). It is likely that the importance of BLB has been underestimated because it is difficult to 
phenotypically differentiate it from $\mathrm{BHB}$, as the two diseases can be found in the same geographic area (Raimundi, 2017).

\section{Plant genetic resistance}

To the best of the authors' knowledge only one study has reported on variations of susceptibility to BLB among coffee genotypes. Sánchez et al. (2003) tested the susceptibility of 16 hybrids, three C. arabica varieties and two species (Coffea canephora and Coffea liberica) to a Pch isolate. The varieties Bourbón, Pacas and Caturra were susceptible to that isolate whereas C. liberica 'Excelsa' and C. canephora 'Robusta' were resistant.

\section{Taxonomy, host range and genetic diversity}

Pseudomonas cichorii is a rod-shaped, strictly aerobic, fluorescent, Gram-negative bacterium that belongs to the Pseudomonadaceae family. Besides coffee, it is also a pathogen of many other plant species of economic importance, including lettuce (Cottyn et al., 2009) and eggplant (Hojo et al., 2008). Phylogenetic studies on Pch are scarce and the very few reported did not include strains obtained from coffee plants with symptoms.

\section{Pathogen detection}

Pseudomonas cichorii identification in diseased samples have been accomplished mostly using morphological, physiological and biochemical methods (Sánchez et al., 2003; Cottyn et al., 2009; Yu \& Lee, 2012; Imriz \& Çinar, 2015). Recently, an ELISA-based method for strains that cause pith necrosis on tomato plants with potential use in the detection of coffee-associated strains was reported (Imriz \& Çinar, 2015). Also, a real-time PCR method based on amplification of the hrpRST region (Cottyn et al., 2011) for specific detection of Pch associated with lettuce was developed, which was successfully used to detect Pch recovered from coffee samples with leaf blight symptoms (Raimundi, 2017). Several genome sequences of coffee-associated Pch strains that could aid in designing methods for host-specific detection of the pathogen are publicly available.

\section{Mechanisms of pathogenicity}

Little effort has been made to understand the molecular mechanisms underlying the ability of Pch to cause disease on coffee plants. Some knowledge about its pathogenicity has been gained studying strains that cause disease on some other host plants. Interestingly, like many other phytopathogenic bacteria, Pch carries a T3SS (Hojo et al., 2008; Ramkumar et al., 2015), but it seems not to be essential for pathogenesis on some host plants. Hojo et al. (2008) demonstrated that the functions of the hrcG, hrcT, hrpL and hrpS genes in Pch SPC9018 are required to cause disease on eggplant (Solanum melongena 'Senryo No. 2'), celery (Apium graveolens
'Topseller'), sweet pepper (Capsicum annuum 'Shosuke') and okra (Abelmoschus esculentus 'Gulliver') but not on lettuce (Lactuca sativa 'Success') plants. Similar Pch dependence on hrp genes to cause disease on some hosts but not on others was observed when hrpW (Kajihara et al., 2012) and hopA1 (Hung et al., 2014) were deleted in strain JBC1. In Pch, the aldH and pat genes, coding for an aldehyde dehydrogenase and a phosphinothricin $N$-acetyltransferase, respectively, are linked to the $h r p$ gene cluster, and their deletions also result in the inability of the bacterium to cause disease on eggplant but not on lettuce (Tanaka et al., 2012). Overall, these observations indicate that Pch uses different mechanisms to cause disease on different hosts. Whether the functions of the brp, aldH or pat genes are required for pathogenicity on coffee plants remains to be determined.

Other genes have also been implicated in the virulence of Pch, including those coding for the formation of the flagellum (fliI and fliJ) (Hung et al., 2016), for the production of the corpeptin-related cyclic lipopeptide cichopeptin A (cipA), and linear lipopeptides of the syringafactin family named cichofactins $\mathrm{A}$ and $\mathrm{B}$ (cifA and cifB) (Pauwelyn et al., 2013; Huang et al., 2015). Lipopeptides are molecules composed of a fatty acid tail linked to an oligopeptide that, due to their amphipathic nature, can insert into plasma membranes forming pores and causing cell death (Raaijmakers et al., 2006).

\section{Coffee leaf scorch}

\section{Disease symptoms, aetiology and dissemination}

Coffee leaf scorch (CLS), also referred to as atrophy of branches, was first recorded in São Paulo state (Paradela Filho et al., 1997), and demonstrated to be caused by X. fastidiosa in 1998 (Lima et al., 1998). The bacterium is transmitted from plant to plant by insects of the Cicadellidae family that acquire it when feeding on infected branches (Silva et al., 2007; Marucci et al., 2008). Although vector transmission is an important factor contributing to short-range dissemination, introduction of the bacterium into new geographic areas is more likely through infected but symptomless plant material (Almeida \& Nunney, 2015). The bacterium colonizes the xylem vessels of host plants, as well as the foregut of its insect vectors (Newman et al., 2004; Chatterjee et al., 2008; Almeida et al., 2012a).

Disease symptoms resemble those caused by nutritional deficiency and herbicide toxicity and are frequently observed in the upper part of the plant. They include plant decay concomitant with chlorosis and defoliation symptoms, leaf malformation, premature leaf senescence at the base of branches, internode shortening (zinc deficiency) (Fig. 1d,e), and reductions in fruit size and quality (Paradela Filho et al., 1997; Lima et al., 1998). As a consequence, plants affected by CLS commonly exhibit dwarfism, marginal necrosis, reduced yield and are more susceptible to abiotic stresses (Rocha et al., 2010a,b; Coletta-Filho et al., 2016). Disease incidence of 
c. $100 \%$ and high severity have been reported in some Brazilian localities (Rocha et al., 2010a).

\section{Plant genetic resistance}

The coffee genetic resistance to $X$. fastidiosa has been poorly investigated. A few reports conducted under field conditions in the Brazilian state of São Paulo indicate variation in the level of infection among C. arabica cultivars, C. liberica varieties and their interspecific hybrids. For instance, it was observed that Acaiá IAC 474-19 was less severely affected by the disease than Catuaí Vermelho IAC 81 in Campinas (Queiroz-Voltan et al., 2006); cultivars Catuaí and Mundo Novo showed more disease severity than other commercial cultivars in Mococa, particularly during rainy periods (QueirozVoltan et al., 2004). Accessions of C. liberica var. liberica, C. liberica var. dewevrei and C. arabica $\times$ C. liberica var. dewevrei exhibited less infection incidence and supported lower bacterial numbers in Londrina, Paraná state (Yorinori et al., 2003). So far, complete resistance to $X$. fastidiosa in Coffea spp. has not been reported.

\section{Taxonomy, host range and genetic diversity}

Xylella fastidiosa is a Gram-negative bacterium that belongs to the family Xanthomonadaceae, order Xanthomonadales of the Gammaproteobacteria. Although the bacterium does not grow on culture media routinely used in the laboratory, several special (well-defined) culture media can be used instead, on which it grows very slowly at an optimal temperature of $26-28^{\circ} \mathrm{C}$. The first disease caused by $X$. fastidiosa was reported in the late 19th century on grapevine in California, USA, and the bacterium properly identified later by Wells et al. (1987). Based on phylogenetic studies, the species has been proposed to consist of several distinct subspecies, namely, fastidiosa (causing Pierce's disease of grapevines and leaf scorch of almond), multiplex (leaf scorch of peach, oak and almond), pauca (Xfp; citrus variegated chlorosis and leaf scorch of coffee and olive), sandyi (leaf scorch of oleander), tashke (isolated from Chitalpa tashkenensis) and morus (leaf scorch of mulberry) (Mendonça et al., 2017; Rapicavoli et al., 2017).

Diseases on different host species caused by strains of subspecies pauca have been reported to be sympatric. For instance, citrus variegated chlorosis (CVC), CLS and olive leaf scorch are all present in some Brazilian states (Coletta-Filho et al., 2016; Francisco et al., 2017). Although there appears to be some degree of host specialization within the subspecies pauca (i.e. strain specificity for either citrus or coffee; Almeida et al., 2008; Prado et al., 2008), cross-infection has been reported (Li et al., 2001; Almeida et al., 2008; Francisco et al., 2017). In addition, some strains that cause CVC and CLS can also cause disease symptoms in several commercial grapevine cultivars ( $\mathrm{Li}$ et al., 2002). Subspecies pauca was also associated with disease symptoms in Prunus persica and Quercus ilex in France (Denancé et al.,
2017) and in olive trees in Italy (Giampetruzzi et al., 2017).

Currently, multilocus sequence typing (MLST) is the most widely accepted genotyping technique for assessing the genetic diversity of $X$. fastidiosa (Nunney et al., 2010, 2014; Yuan et al., 2010). However, it has been shown that even MLST is not enough to distinguish between closely related strains, sometimes requiring the use of additional gene sequences (Bleve et al., 2016). In any case, an MLST system based on seven housekeeping genes (leuA, petC, malF, cysG, holC, nuoL and glrT) to rapidly classify $X$. fastidiosa strains into sequence types (STs) has been proposed (Yuan et al., 2010; Nunney et al., 2014). This system provides good insights into the phylogenetic position of the strains but is not clearly associated with host specificity.

Considerable effort has been made to study the genetic variability of $X$. fastidiosa populations that cause disease on coffee, citrus and olive (Almeida et al., 2008; Nunney et al., 2012; Saponari et al., 2013; Elbeaino et al., 2014; Haelterman et al., 2015; Coletta-Filho et al., 2016). Phylogenetic analysis using different molecular markers has consistently grouped strains from coffee and citrus in a distinct monophyletic group separated from strains from North America. Overall, those studies also indicate that citrus strains are genetically different from coffee strains, but that some recombination between the two populations can occur (Almeida et al., 2008; Nunney et al., 2012). MLST analysis showed that different $X$. fastidiosa STs can cause disease on the same host plant (ColettaFilho et al., 2016; Bergsma-Vlami et al., 2017), in particular on C. arabica (Bergsma-Vlami et al., 2017). Also, the same ST can cause disease on different host plants (Nunney et al., 2014) and the same ST that affects coffee plants has been recorded in very distant geographic areas (Loconsole et al., 2014; Nunney et al., 2014; Almeida \& Nunney, 2015; Coletta-Filho et al., 2016). Importantly, sequence types ST72 and ST76, corresponding to subspecies sandyi, were identified in coffee samples intercepted in France (Denancé et al., 2017) and Italy (Loconsole et al., 2014; Marcelletti \& Scortichini, 2016).

Results of several studies have demonstrated a high rate of genetic recombination among $X$. fastidiosa strains (Almeida et al., 2008; Jacques et al., 2016; Coletta-Filho et al., 2017; Denancé et al., 2017). Importantly, genetic recombination between citrus and coffee strains collected from citrus and coffee plants with symptoms was evidenced by the sequences of the gene markers leuA, $r f b D$, petC, malF, cysG and holC (Almeida et al., 2008; Nunney et al., 2012). Based on their observations, Nunney et al. (2012) suggested that Xfp became pathogenic to citrus and coffee recently via intersubspecific recombination, possibly via introgression from subspecies multiplex, and concluded that recombination contributes more than point mutations to the genetic variation of $X$. fastidiosa. Such a high rate of recombination makes it difficult to make phylogenetic inferences and develop reliable methods for detection.

Besides the high rate of genetic recombination revealed by MLST analysis, clear understanding of the biology of 
$X$. fastidiosa is further complicated by the large proportion of flexible gene pools present in its genomes. In a genome comparison study, differences in the flexible genome among $X$. fastidiosa strains causing disease in diverse hosts were found (Nunes et al., 2003). Several genomic islands, some of them putatively associated with pathogenicity, were identified. Notably, citrus and coffee strains share genomic islands (such as $\mathrm{GI}_{1}$ ) not present in strains that infect other hosts. It was estimated that the flexible pool of $X$. fastidiosa constitutes at least $18 \%$ of the total genome (Nunes et al., 2003).

\section{Pathogen detection}

Several immunological and molecular methods for specific detection of $X$. fastidiosa have been developed by diverse research groups (comprehensively reviewed by Baldi \& La Porta (2017)). Some of the PCR-based methods were designed to detect the pathogen at the species level using primers targeted to genomic regions conserved among all subspecies (Francis et al., 2006), others to differentiate among a subset of subspecies (Hernandez-Martinez et al., 2006), and yet others to detect a specific subspecies (Pooler \& Hartung, 1995; Brady et al., 2012). Although it is believed that the method that best discriminates among $X$. fastidiosa strains is MLST (Almeida et al., 2008; Yuan et al., 2010; Nunney et al., 2012), lack of correlation has been observed between detection using subspecies-specific primers and MLST (Denancé et al., 2017). Recently, a protocol referred to as single nucleotide primer extension ( $\mathrm{SNuPE}$ ) to differentiate between citrus and coffee strains was proposed (Montes-Borrego et al., 2015). The authors of this protocol noticed that SNPs present in the gyrB locus were able to better discriminate between these two populations than the loci commonly used in MLST.

\section{Mechanisms of pathogenicity}

Studies on the molecular mechanisms underlying the pathogenicity of $X$. fastidiosa toward coffee plants have not been published. The vast majority of knowledge on the pathogenicity of $X$. fastidiosa has been obtained from strains that cause Pierce's disease and CVC (Mendonça et al., 2017; Rapicavoli et al., 2017). It is presumed that some of those mechanisms are shared among strains that cause disease on different host species. As in other hosts (De Souza et al., 2004; Cardinale et al., 2018), X. fastidiosa forms extensive biofilms in the xylem vessels of coffee plants causing their occlusion (Alves et al., 2004), which is thought to be responsible for nutrient deficiency and poor development of aerial parts.

Several bacterial factors contribute to biofilm formation. The importance of the Rpf (for regulation of pathogenicity factors) quorum-sensing regulatory system and the diffusible signal factor (DSF) for biofilm formation and disease development in host plants as well as in insect vectors for bacterium transmission has been demonstrated (Newman et al., 2004; Almeida et al., 2012a; Ionescu et al., 2014). Similarly, the involvement of the extracellular polysaccharide (EPS; Killiny et al., 2013), T4P (Smolka et al., 2003; Meng et al., 2005; De La Fuente et al., 2007, 2008; Li et al., 2007) and genes coding for adhesins (Van Sluys et al., 2002; Guilhabert \& Kirkpatrick, 2005; Voegel et al., 2010) in X. fastidiosa biofilm formation and virulence has also been well documented. Adhesins are high molecular weight proteins that are predicted to be secreted by type $\mathrm{V}$ secretion systems (T5SS) (De Souza et al., 2004).

Xylella fastidiosa possesses the main bacterial secretion systems, except for the T3SS, which is usually required for pathogenicity (Mendonça et al., 2017; Rapicavoli et al., 2017). The absence of a T3SS could explain why gene-for-gene resistance has not been observed in its host species. It is believed that bacterial colonization, mobilization of plant nutrients and subversion of plant defence responses are facilitated by the function of the type II secretion system (T2SS) (Roper et al., 2007; Pérez-Donoso et al., 2010). Reports on the contribution of the type I and type IV secretion systems to the pathogenicity of $X$. fastidiosa have not been published. Importantly, several studies conducted with mutations in genes coding for proteins secreted by T2SS (Gouran et al., 2016; Nascimento et al., 2016), T5SS (Guilhabert \& Kirkpatrick, 2005; Voegel et al., 2010) as well as with quorum-sensing rpf mutants (Ionescu et al., 2014) revealed that the ability of $X$. fastidiosa to form biofilm and to cause disease symptoms can be uncoupled. Consistently, lack of correlation between severity of symptoms and bacterial biofilm formation in the xylem vessels was observed in other studies (Newman et al., 2003; Alves et al., 2004). Those results challenge the notion that the ability of $X$. fastidiosa to cause disease depends exclusively on occlusion of the xylem vessels.

\section{Minor bacterial diseases}

Bacterial leaf spot symptoms caused by $P$. syringae pv. syringae (Pss) on coffee trees have been reported in Puerto Rico (Cortés Monllor, 1988) and Africa (Baker, 1972; Ramos \& Shavdia, 1976; Okioga, 1977). The disease is particularly important in nurseries, in which it can cause plant losses of up to $85 \%$ (Ramos \& Shavdia, 1976; Okioga, 1977). In Brazil, similar symptoms have been reported for Psgc (Franco Do Amaral et al., 1958; Ramos \& Shavdia, 1976), Pch (Robbs et al., 1974; Almeida et al., 2012b; Raimundi, 2017), Psta (Rodrigues et al., 2006, 2017c; Destéfano et al., 2010) and Robbsia andropogonis (Ran) (Lopes-Santos et al., 2017; Rodrigues et al., 2017c), making disease diagnosis difficult in the absence of isolation and characterization of the causal agent or of appropriate detection methods. It is not clear if the importance of the disease caused by Pss has been underestimated because it is confused with BHB caused by Psgc or if some misidentification of the aetiologic agent has occurred. A guidance to biochemical identification of bacteria causing necrotic spot symptoms in coffee trees has been provided by Rodrigues et al. 
(2013). However, simpler and more reliable molecular or serological methods are required.

Robbsia andropogonis was recorded causing the disease bacterial brown spot on C. arabica in nursery plants in Brazil (Rodrigues Neto et al., 1981). This species has a broad host range affecting plants belonging to different families (Lopes-Santos et al., 2017). Nevertheless, it has not been found constantly associated with disease in commercial coffee plantations resulting in severe losses.

\section{Concluding remarks}

Recurrent outbreaks of bacterial diseases cause significant damage to coffee crops especially in nurseries. One of the major limitations to efficiently control these diseases is the lack of appropriate methods for early detection of the aetiologic agents. In the case of pseudomonads, comparative genomics studies could help identify regions that are specific to each bacterial pathogen and could be useful for the development of sensitive, rapid and simple serological or DNA-amplification-based methods. In that regard, efforts should be made to develop not only methods that require considerable laboratory infrastructure but also methods that could be applied directly in the orchard without the need for highly qualified professionals, such as loop-mediated isothermal amplification (LAMP) or recombinase polymerase amplification (Donoso \& Valenzuela, 2018). More efforts should also be made to try to determine the genetic variability and virulence/aggressiveness of the pseudomonad populations causing blight symptoms on coffee plants, which is important for plant resistance selection and deployment. In the case of X. fastidiosa, considering its high rates of recombination and introgression, permanent revision of the virulence and genetic variability is necessary, which has direct implication on the specificity of the detection methods. In the absence of evidence for the existence of complete resistance against these coffee bacterial pathogens, it is important to undertake studies aimed to understand the molecular mechanisms underlying horizontal resistance and to identify genes associated with it. Comparative transcriptomic, proteomic and genome-wide association studies (GWAS) could provide important insights into the mechanisms underlying this type of resistance. Such information can be useful for plant breeding or biotechnology programmes in order to obtain genotypes with enhanced (and probable durable) field resistance.

\section{Acknowledgements}

The authors thank the Brazilian agencies CAPES (Coordenação de Aperfeiçoamento de Pessoal de Nível Superior), CNPq (Conselho Nacional de Desenvolvimento Científico e Tecnológico) and FAPEMIG (Fundação de Amparo à Pesquisa de Minas Gerais) for providing financial support to conduct research in their laboratories. The authors also declare no conflict of interest. The content of this review is the exclusive responsibility of the authors and not of the funding agencies.

\section{References}

Ahn SY, Baek K-H, Moon YS, Yun HK, 2013. Theobroxide treatment inhibits wild fire disease occurrence in Nicotiana benthamiana by the overexpression of defense-related genes. Plant Pathology Journal 29, 110-5.

Alfano JR, Charkowski AO, Deng W-L et al., 2000. The Pseudomonas syringae Hrp pathogenicity island has a tripartite mosaic structure composed of a cluster of type III secretion genes bounded by exchangeable effector and conserved effector loci that contribute to parasitic fitness and pathogenicity in plants. Proceedings of the National Academy of Sciences of the United States of America 97, 4856-61.

Almeida RPP, Nunney L, 2015. How do plant diseases caused by Xylella fastidiosa emerge? Plant Disease 99, 1457-67.

Almeida RPP, Nascimento FE, Chau J et al., 2008. Genetic structure and biology of Xylella fastidiosa causing disease in citrus and coffee in Brazil. Applied and Environmental Microbiology 74, 3690-701.

Almeida NF, Yan S, Lindeberg M et al., 2009. A draft genome sequence of Pseudomonas syringae pv. tomato T1 reveals a type III effector repertoire significantly divergent from that of Pseudomonas syringae pv. tomato DC3000. Molecular Plant-Microbe Interactions 22, 52-62.

Almeida PP, Killiny N, Newman KL, Chatterjee S, Ionescu M, Lindow SE, 2012a. Contribution of RfpB to cell-to-cell signal synthesis, virulence, and vector transmission of Xylella fastidiosa. Molecular Plant-Microbe Interactions 25, 453-62.

Almeida IMG, Rodrigues LMR, Patrício FRA, 2012b. Crestamento bacteriano das folhas causado por Pseudomonas cichorii em café no estado de São Paulo. Summa Phtytopathologica 38 (Suppl.), 261.

Alves E, Marucci CR, Lopes JRS, Leite B, 2004. Leaf symptoms on plum, coffee and citrus and the relationship with the extent of xylem vessels colonized by Xylella fastidiosa. Journal of Phytopathology 152, 291-7.

Amaral JF, Teixeira C, Pinheiro ED, 1956. A bactéria causadora da mancha aureolada do cafeeiro. Arquivos do Instituto Biológico 23, 151-5.

Anzai H, Yoneyama K, Yamaguchi I, 1989. Transgenic tobacco resistant to a bacterial disease by the detoxification of a pathogenic toxin. Molecular and General Genetics 219, 492-4.

Anzai H, Yoneyama K, Yamaguchi I, 1990. The nucleotide sequence of tabtoxin resistance gene (ttr) of Pseudomonas syringae pv. tabaci. Nucleic Acids Research 18, 1890.

Araújo GG, Rodrigues F, Gonçalves FLT, Galante D, 2018. Survival and ice nucleation activity of Pseudomonas syringae strains exposed to simulated high-altitude atmospheric conditions. bioRxiv. https://doi. org/10.1101/408906.

Badel JL, Nomura K, Bandyopadhyay S, Shimizu R, Collmer A, She SY, 2003. Pseudomonas syringae pv. tomato DC3000 HopPtoM (CEL ORF3) is important for lesion formation but not growth in tomato and is secreted and translocated by the Hrp type III secretion system in a chaperone-dependent manner. Molecular Microbiology 49, 1239-51.

Badel JL, Shimizu R, Oh H-S, Collmer A, 2006. A Pseudomonas syringae pv. tomato avrE1/hopM1 mutant is severely reduced in growth and lesion formation in tomato. Molecular Plant-Microbe Interactions 19, 99-111.

Bai X, Zhou L, Hu Y, Ji G, Li J, Zhang H, 2013. Isolation and identification of the pathogen of coffee bacterial blight disease. Chinese Journal of Tropical Crops 34, 738-42.

Baker CJ, 1972. Solai die-back. Coffee Research Foundation Annual Report, 1971-72. Kiambu, Kenya: Coffee Research Foundation, 72.

Baldi P, La Porta N, 2017. Xylella fastidiosa: host range and advance in molecular identification techniques. Frontiers in Plant Science 8, 944.

Barta TM, Willis DK, 2005. Biological and molecular evidence that Pseudomonas syringae pathovars coronafaciens, striafaciens and garcae are likely the same pathovar. Journal of Phytopathology 153, 492-9. 
Batchvarova R, Nikolaeva V, Slavov S et al., 1998. Transgenic tobacco cultivars resistant to Psendomonas syringae pv. tabaci. Theoretical and Applied Genetics 97, 986-9.

Belan LL, Pozza EA, Freitas MLO, Raimundi MK, Souza RM, Machado JC, 2016. Occurrence of Pseudomonas syringae pv. garcae in coffee seeds. Australasian Journal of Crop Science 10, 1015-21.

Bender CL, Alarcón-Chaidez F, Gross DC, 1999. Pseudomonas syringae phytotoxins: mode of action, regulation, and biosynthesis by peptide and polyketide synthetases. Microbiology and Molecular Biology Reviews 63, 266-92.

Bergsma-Vlami M, van de Bilt JLJ, Tjou-Tam-Sin NNA et al., 2017. Assessment of the genetic diversity of Xylella fastidiosa in imported ornamental Coffea arabica plants. Plant Pathology 66, 1065-74.

Beriam LOS, Almeida IMG, Suzete AL et al., 2006. Pseudomonas syringae pv. tabaci in papaya seedlings. Summa Phytopathologica 32, 21-6.

Bhatti KH, Xu C, Wu J, He C, 2008. Overexpression of rice OsLOL2 gene confers disease resistance in tobacco to Pseudomonas syringae pv. tabaci. Progress in Natural Science 18, 807-12.

Bleve G, Marchi G, Ranaldi F et al., 2016. Molecular characteristics of a strain (Salento-1) of Xylella fastidiosa isolated in Apulia (Italy) from an olive plant with the quick decline syndrome. Phytopathologia Mediterranea 55, 139-46.

Bradbury JF, 1986. Guide to Plant Pathogenic Bacteria. Slough, UK: $\mathrm{CAB}$ International.

Brady JA, Faske JB, Ator RA, Castaneda-Gill JM, Mitchell FL, 2012. Probe-based real-time PCR method for multilocus melt typing of Xylella fastidiosa strains. Journal of Microbiological Methods 89, $12-7$.

Burk LG, Heggestad HE, 1966. The genus Nicotiana: a source of resistance to disease of cultivated tobacco. Economic Botany 20, 76-88.

CABI, 2018. Invasive species compendium - Pseudomonas syringae pv. tabaci (wildfire). [https://www.cabi.org/isc/datasheet/45016]. Accessed 3 September 2018.

Cafepoint, 2011. Pesquisadores alertam para mancha aureolada. [https:// www.cafepoint.com.br/noticias/giro-de-noticias/pesquisadores-alertampara-mancha-aureolada-69220n.aspx]. Accessed 20 March 2018.

Cao Y, Yang Y, Zhang H, Li D, Zheng Z, Song F, 2008. Overexpression of a rice defense-related F-box protein gene OsDRF1 in tobacco improves disease resistance through potentiation of defense gene expression. Physiologia Plantarum 134, 440-52.

Cardinale M, Luvisi A, Meyer JB et al., 2018. Specific fluorescence in situ hybridization (FISH) test to highlight colonization of xylem vessels by Xylella fastidiosa in naturally infected olive trees (Olea europaea L.). Frontiers in Plant Science 9, 431.

Cardoso RML, Sera T, 1983. Obtenção de cultivares de Coffea arabica L. com resistência simultânea a Hemileia vastatrix Berk. \& Br. e Pseudomonas syringae pv. garcae Amaral et al. no Estado do Paraná. In: Simpósio sobre Ferrugens do Cafeeiro. Oeiras, Portugal: CIFC/IICT L, 417-9.

Carmona MJ, Molina A, Fernandez JA, López-Fando JJ, García-Olmedo F, 1993. Expression of the $\alpha$-thionin gene from barley in tobacco. The Plant Journal 3, 457-62.

Carnielli A, de Souza-Kiihl RA, Almeida LA, da Silva CM, 1992. Cultivares de soja EMBRAPA 2 e EMBRAPA 3. EMBRAPA-UEPAE Dourados. Comunicado Técnico 46, 1-3.

Cha JY, Lee JS, Oh JI, Choi JW, Baik HS, 2008. Functional analysis of the role of Fur in the virulence of Pseudomonas syringae pv. tabaci 11528: Fur controls expression of genes involved in quorum-sensing. Biochemical and Biophysical Research Communications 366, 281-7.

Cha JY, Lee CD, Lee JS, Oh JI, Baik HS, 2012. GacA directly regulates expression of several virulence genes in Pseudomonas syringae pv. tabaci 11528. Biochemical and Biophysical Research Communications $417,665-72$.

Chatterjee S, Almeida RPP, Lindow SE, 2008. Living in two worlds: the plant and insect lifestyles of Xylella fastidiosa. Annual Review of Phytopathology 46, 243-71.
Chen Z, 2002. Morphocultural and Pathogenic Comparisons between Colletotrichum kahawae and C. gloeosporioides Isolated from Coffee Berries. Lisbon, Portugal: Instituto Superior de Agronomia da Universidade Técnica de Lisboa, PhD thesis.

Clayton EE, 1934. Toxin produced by Bacterium tabacum and its relation to host range. Journal of Agricultural Research 48, 411-26.

Clayton EE, 1947. A wildfire resistant tobacco. Journal of Heredity 38 , $35-40$.

Cole D, 1999. The efficacy of acibenzolar-S-methyl, an inducer of systemic acquired resistance, against bacterial and fungal diseases of tobacco. Crop Protection 18, 267-73.

Coletta-Filho HD, Francisco CS, Lopes JRS, Oliveira AF, Silva LFDO, 2016. First report of olive leaf scorch in Brazil, associated with Xylella fastidiosa subsp. pauca. Phytopathologia Mediterranea 55, 130-5.

Coletta-Filho HD, Francisco CS, Lopes JRS, Muller C, Almeida RPP, 2017. Homologous recombination and Xylella fastidiosa hostpathogen associations in South America. Phytopathology 107, 305-12.

Collmer A, Badel JL, Charkowski AO et al., 2000. Pseudomonas syringae Hrp type III secretion system and effector proteins. Proceedings of the National Academy of Sciences of the United States of America 97, 8770-7.

Cortés Monllor A, 1988. Bacterial leaf spot of coffee. Journal of Agriculture of the University of Puerto Rico 72, 621-3.

Cottyn B, Heylen K, Heyrman J et al., 2009. Pseudomonas cichorii as the causal agent of midrib rot, an emerging disease of greenhousegrown butterhead lettuce in Flanders. Systematic and Applied Microbiology 32, 211-25.

Cottyn B, Baeyen S, Pauwelyn E et al., 2011. Development of a real-time PCR assay for Pseudomonas cichorii, the causal agent of midrib rot in greenhouse-grown lettuce, and its detection in irrigating water. Plant Pathology 60, 453-61.

De La Fuente L, Burr TJ, Hoch HC, 2007. Mutations in type I and type IV pilus biosynthetic genes affect twitching motility rates in Xylella fastidiosa. Journal of Bacteriology 189, 7507-10.

De La Fuente L, Burr TJ, Hoch HC, 2008. Autoaggregation of Xylella fastidiosa cells is influenced by type I and type IV pili. Applied and Environmental Microbiology 74, 5579-82.

De Souza AA, Takita MA, Coletta-Filho HD et al., 2004. Gene expression profile of the plant pathogen Xylella fastidiosa during biofilm formation in vitro. FEMS Microbiology Letters 237, 341-53.

DeGray G, Rajasekaran K, Smith F, Sanford J, Daniell H, 2001. Expression of an antimicrobial peptide via the chloroplast genome to control phytopathogenic bacteria and fungi. Plant Physiology 127, $852-62$.

Denancé N, Legendre B, Briand M et al., 2017. Several subspecies and sequence types are associated with the emergence of Xylella fastidiosa in natural settings in France. Plant Pathology 66, 1054-64.

Deng W-L, Rehm AH, Charkowski AO, Rojas CM, Collmer A, 2003. Pseudomonas syringae exchangeable effector loci: sequence diversity in representative pathovars and virulence function in P. syringae pv. syringae B728a. Journal of Bacteriology 185, 2592-602.

Destéfano SAL, Rodrigues LMR, Beriam LOS, Patrício FRA, Thomaziello RA, Rodrigues-Neto J, 2010. Bacterial leaf spot of coffee caused by Pseudomonas syringae pv. tabaci in Brazil. Plant Pathology 59, 1162-3.

Donoso A, Valenzuela S, 2018. In-field molecular diagnosis of plant pathogens: recent trends and future perspectives. Plant Pathology 67, 1451-61.

Elbeaino T, Valentini F, Kubaa RA, Mourabak P, Yaseen T, Digiaro M, 2014. Multilocus sequence typing of Xylella fastidiosa isolated from olive affected by 'olive quick decline syndrome' in Italy. Phytopathologia Mediterranea 53, 533-42.

Francis M, Lin H, Cabrera-La Rosa J, Doddapaneni H, Civerolo EL, 2006. Genome-based PCR primers for specific and sensitive detection and quantification of Xylella fastidiosa. European Journal of Plant Pathology 115, 203-13.

Francisco CS, Ceresini PC, Almeida RPP, Coletta-Filho HD, 2017. Spatial genetic structure of coffee-associated Xylella fastidiosa 
populations indicates that cross infection does not occur with sympatric citrus orchards. Phytopathology 107, 395-402.

Franco Do Amaral J, Teixeira C, Pinheiro ED, 1958. The bacterium causing halo blight of coffee. Review of Applied Mycology 32, 42.

Gardan L, Shafik H, Belouin S, Broch R, Grimont F, 1999. DNA relatedness among the pathovars of Pseudomonas syringae and description of Pseudomonas tremae sp. nov. and Pseudomonas cannabina sp. nov. (ex Sutic and Dowson 1959). International Journal of Systematic Bacteriology 49, 469-78.

Ger MJ, Chen C-S, Hwang S-Y et al., 2003. Constitutive expression of hrap gene in transgenic tobacco plant enhances resistance against virulent bacterial pathogens by induction of a hypersensitive response. Molecular Plant-Microbe Interactions 15, 764-73.

Giampetruzzi A, Saponari M, Loconsole G et al., 2017. Genome-wide analysis provides evidence on the genetic relatedness of the emergent Xylella fastidiosa genotype in Italy to isolates from Central America. Phytopathology 107, 816-27.

Gimenez-Ibanez S, Boter M, Fernández-Barbero G, Chini A, Rathjen JP, 2014. The bacterial effector HopX1 targets JAZ transcriptional repressors to activate jasmonate signaling and promote infection in Arabidopsis. PLoS Biology 12, e1001792.

Gonçalves FLT, Massambani O, 2011. Bacteria and fungal spores as ice nuclei from Coffea arabica L. Ciência Natura 33, 73.

Gouran H, Gillespie H, Nascimento R et al., 2016. The secreted protease PrtA controls cell growth, biofilm formation and pathogenicity in Xylella fastidiosa. Scientific Reports 6, 31098.

Goy PA, Feliz G, Métrux JP, Meins F Jr, 1992. Resistance to disease in the hybrid Nicotiana glutinosa $\times$ Nicotiana debneyi is associated with high constitutive levels of $\beta$-1,3-glucanase, chitinase, peroxidase and polyphenoloxidase. Physiological and Molecular Plant Pathology 41, 11-21.

Großkinsky DK, Naseem M, Abdelmohsen UR et al., 2011. Cytokinins mediate resistance against Pseudomonas syringae in tobacco through increased antimicrobial phytoalexin synthesis independent of salicylic acid signalling. Plant Physiology 157, 815-30.

Guilhabert MR, Kirkpatrick BC, 2005. Identification of Xylella fastidiosa antivirulence genes: hemagglutinin adhesins contribute to $X$. fastidiosa biofilm maturation and colonization and attenuate virulence. Molecular Plant-Microbe Interactions 8, 856-68.

Guo ZJ, Chen XJ, Wu XL, Ling JQ, Xu P, 2004. Overexpression of the AP2/EREBP transcription factor OPBP1 enhances disease resistance and salt tolerance in tobacco. Plant Molecular Biology 55, 607-18.

Haelterman RM, Tolocka PA, Roca ME, Guzmán FA, Fernández FD, Otero ML, 2015. First presumptive diagnosis of Xylella fastidiosa causing olive scorch in Argentina. Journal of Plant Pathology 97, $391-403$.

Hao G, Zhang S, Stover E, 2017. Transgenic expression of antimicrobial peptide D2A21 confers resistance to diseases incited by Pseudomonas syringae pv. tabaci and Xanthomonas citri, but not Candidatus Liberibacter asiaticus. PLOS ONE 12, e0186810.

Herms S, Seehaus K, Koehle H, Conrath U, 2002. A strobilurin fungicide enhances the resistance of tobacco against Tobacco mosaic virus and Pseudomonas syringae pv. tabaci. Plant Physiology 130, 120-7.

Hernandez-Martinez R, Costa HS, Dumenyo CK, Cooksey DA, 2006. Differentiation of strains of Xylella fastidiosa infecting grape, almonds, and oleander using a multiprimer PCR assay. Plant Disease 90, 1382-8.

Hinkosa GG, Lencho A, Selvaraj T, Chavhan A, Sadessa K, 2016. Screening, cultural and biochemical characterization of coffee bacterial blight (Pseudomonas syringae pv. garcae van Hall) isolates from Sidama and Gedeo zones, SNNP Regional State, Ethiopia. International Journal of Life Sciences 4, 491-508.

Hinkosa GG, Lencho A, Selvaraj T, Sadessa K, 2017. Pathogenicity and molecular characterization of coffee bacterial blight (Pseudomonas syringae pv. garcae van Hall) isolates from Sidama and Gedeo Zones, SNNP Regional State, Ethiopia. International Journal of Life Sciences $5,35-45$.
Hojo H, Koyanagi M, Tanaka M et al., 2008. The hrp genes of Pseudomonas cichorii are essential for pathogenicity on eggplant but not on lettuce. Microbiology 154, 2920-8.

Huang Y, Nordeen RO, Di M, Owens LD, McBeath JH, 1997. Expression of an engineered cecropin gene cassette in transgenic tobacco plants confers disease resistance to Pseudomonas syringae pv. tabaci. Phytopathology 87, 494-9.

Huang EH, Ger M-J, Yip M-K, Chen C-Y, Pandey A-K, Feng T-Y, 2004. A hypersensitive response was induced by virulent bacteria in transgenic tobacco plants overexpressing a plant ferredoxin-like protein (PFLP). Physiological and Molecular Plant Pathology 64, 103-10.

Huang C-J, Pauwelyn E, Ongena M et al., 2015. Characterization of cichopeptins, new phytotoxic cyclic lipodepsipeptides produced by Pseudomonas cichorii SF1-54 and their role in bacterial midrib rot disease of lettuce. Molecular Plant-Microbe Interactions 28, 1009-22.

Hung NB, Ramkumar G, Lee YH, 2014. An effector gene hopA1 influences on virulence, host specificity, and lifestyles of Pseudomonas cichorii JBC1. Research in Microbiology 165, 620-9.

Hung NB, Ramkumar G, Bhattacharyya D, Lee YH, 2016. Elucidation of the functional role of flagella in virulence and ecological traits of Pseudomonas cichorii using flagella absence $(\Delta f l i J)$ and deficiency ( $\Delta$ fliI) mutants. Research in Microbiology 167, 262-71.

Ichinose Y, Shimizu R, Ikeda Y et al., 2003. Need for flagella for complete virulence of Pseudomonas syringae pv. tabaci: genetic analysis with flagella-defective mutants $\Delta f l i C$ and $\Delta f l i D$ in host tobacco plants. Journal of General Plant Pathology 69, 244-9.

Imriz G, Çinar Ö, 2015. ELISA-based and traditional diagnosis methods for identification of Pseudomonas cichorii and Pseudomonas corrugata causing pith necrosis on tomato plants. Journal of Bahri Dagdas Crop Research 3, 7-13.

Ionescu M, Zaini PA, Baccari C, Tran S, da Silva AM, Lindow SE, 2014. Xylella fastidiosa outer membrane vesicles modulate plant colonization by blocking attachment to surfaces. Proceedings of the National Academy of Sciences of the United States of America 111, E3910-8.

Ithiru JM, Gichuru EK, Gitonga PN, Cheresek JJ, Gichimu BM, 2013. Methods for early evaluation for resistance to bacterial blight of coffee. African Journal of Agricultural Research 8, 2450-4.

Ito DS, Sera GH, Sera T et al., 2005. Resistência da cultivar de café IPR 102 à mancha aureolada (Pseudomonas syringae pv. garcae). SBPN Scientific Journal 9, 33.

Ito DS, Sera T, Sera GH, Del Grossi L, Kanayama FS, 2008. Resistance to bacterial blight in arabica coffee cultivars. Crop Breeding and Applied Biotechnology 8, 99-103.

Jacques M-A, Denancé N, Legendre B et al., 2016. New coffee plantinfecting Xylella fastidiosa variants derived via homologous recombination. Applied and Environmental Microbiology 82, 1556-68.

Kairu GM, 1997. Biochemical and pathogenic differences between Kenyan and Brazilian isolates of Pseudomonas syringae pv. garcae. Plant Pathology 46, 239-46.

Kajihara S, Hojo H, Koyanagi M et al., 2012. Implication of hrpW in virulence of Pseudomonas cichorii. Plant Pathology 61, 335-63.

Kawakita Y, Taguchi F, Inagaki Y, Toyoda K, Shiraishi T, Ichinose Y, 2012. Characterization of each aefR and mexT mutant in Pseudomonas syringae pv. tabaci 6605. Molecular Genetics and Genomics 287, 473-84.

Killiny N, Martinez RH, Dumenyo CK, Cooksey DA, Almeida RP, 2013. The exopolysaccharide of Xylella fastidiosa is essential for biofilm formation, plant virulence, and vector transmission. Molecular PlantMicrobe Interactions 26, 1044-53.

Kimura O, Robbs CF, Ribeiro RLD, 1973. Estudos sobre o agente da 'mancha aureolada do cafeeiro' (Pseudomonas garcae Amaral et al.). Arquivos da Universidade Federal Rural do Rio de Janeiro 3, 15-8.

Kimura O, Robbs CF, Ferrari JAR, 1976. Algunas observaciones relacionadas con las bacteriosis de cafeiro. In: Congresso de Pesquisas Cafeeiras 4, Guarapari. Rio de Janeiro, Brazil: IBC/GERCA, 104. 
Korobko A, Wondinagegne E, 1997. Bacterial blight of coffee (Pseudomonas syringae pv. garcae) in Ethiopia. In: Rudoldh K, Burr TJ, Mansfield JW, Stead D, Vivian A, Von Kietzele J, eds. Pseudomonas syringae and Related Pathogens. Dordrecht, Netherlands: Springer, 538-41.

Lee S, Yang DS, Uppalapati SR, Summer LW, Mysore KS, 2013. Suppression of plant defense responses by extracellular metabolites from Pseudomonas syringae pv. tabaci in Nicotiana benthamiana. BMC Plant Biology 13, 65.

Li W-B, Pria WD, Teixeira C et al., 2001. Coffee leaf scorch caused by a strain of Xylella fastidiosa from citrus. Plant Disease 85, 501-5.

Li W-B, Zhou C-H, Pria WD Jr et al., 2002. Citrus and coffee strains of Xylella fastidiosa induce Pierce's disease in grapevine. Plant Disease 86, 1206-10.

Li Y, Hao G, Galvani CD et al., 2007. Type I and type IV pili of Xylella fastidiosa affect twitching motility, biofilm formation and cell-cell aggregation. Microbiology 153, 719-26.

Li Z, Dhekhey SA, Gray DJ, 2011. PR-1 gene family of grapevine: a uniquely duplicated PR1 gene from a Vitis interspecific hybrid confers high level resistance to bacterial disease in transgenic tobacco. Plant Cell Reports 30, 1-11.

Lima JEO, Miranda VS, Hartung JS et al., 1998. Coffee leaf scorch bacterium: axenic culture, pathogenicity, and comparison with Xylella fastidiosa of citrus. Plant Disease 82, 94-7.

Liu H, Zhang H, Yang Y et al., 2008. Functional analysis reveals pleiotropic effects of rice RING-H2 finger protein gene OsBIRF1 on regulation of growth and defense responses against abiotic and biotic stresses. Plant Molecular Biology 68, 17-30.

Loconsole G, Potere O, Boscia D et al., 2014. Detection of Xylella fastidiosa in olive trees by molecular and serological methods. Journal of Plant Pathology 96, 7-14.

Lopes-Santos L, Castro DBA, Ferreira-Tonin M et al., 2017. Reassessment of the taxonomic position of Burkholderia andropogonis and description of Robbsia andropogonis gen. nov., comb. nov. Antonie van Leeuwenhoek 110, 727-36.

Maciel KW, Destefano SAL, Beriam LOS et al., 2018. Bacterial halo blight of coffee crop: aggressiveness and genetic diversity of strains. Bragantia 77, 96-106.

Maia T, Badel JL, Marin-Ramirez G et al., 2016. The Hemileia vastatrix effector HvEC-016 suppresses bacterial blight symptoms in coffee genotypes with the SH1 rust resistance gene. New Phytologist 213, 1315-29.

Malavolta Júnior VA, Almeida IMG, Rodrigues Neto J, Beriam LOS, 2008. Bactérias fitopatogênicas assinaladas no Brasil: uma atualização. Summa Phytopathologica 34, 988.

Marcelletti S, Scortichini M, 2016. Xylella fastidiosa CoDiRO strain associated with the olive quick decline syndrome in southern Italy belongs to a clonal complex of the subspecies pauca that evolved in Central America. Microbiology 162, 2087-98.

Marucci RC, Lopes JRS, Cavichioli RR, 2008. Transmission efficiency of Xylella fastidiosa by sharpshooters (Hemiptera: Cicadellidae) in coffee and citrus. Journal of Economic Entomology 101, 1114-21.

Marutani M, Taguchi F, Ogawa Y et al., 2008. Gac two-component system in Pseudomonas syringae pv. tabaci is required for virulence but not for hypersensitive reaction. Molecular Genetics and Genomics $279,313-22$.

Mendonça LBP, Zambolim L, Badel JL, 2017. Bacterial citrus diseases: major threats and recent progress. Journal of Bacteriology \& Mycology 5, 00143.

Meng Y, Yaxin L, Galvani CD et al., 2005. Upstream migration of Xylella fastidiosa via pilus-driven twitching motility. Journal of Bacteriology 187, 5560-7.

Mitsuhara I, Matsufuru H, Ohshima M et al., 2000. Induced expression of sarcotoxin IA enhanced host resistance against both bacterial and fungal pathogens in transgenic tobacco. Molecular Plant-Microbe Interactions $13,860-8$.
Mohan SK, 1976. Investigações sobre Pseudomonas garcae Amaral et al. em cafeeiros. In: Congresso Brasileiro de Pesquisas Cafeeiras 4, Caxambu. Rio de Janeiro, Brazil: IBC/GERCA, 56.

Mohan SK, Cardoso RML, Paiva MA, 1978. Resistência em germoplasma de Coffea ao crestamento bacteriano incitado por Pseudomonas garcae Amaral et al. Pesquisa Agropecuária Brasileira 13, 53-64.

Montes-Borrego M, Lopes JRS, Jiménez-Díaz RM, Landa BB, 2015. Combined use of a new SNP-based assay and multilocus SSR markers to assess genetic diversity of Xylella fastidiosa subsp. pauca infecting citrus and coffee plants. International Microbiology 18, 13-24.

Moraes SA, Sugimore MH, Tomazello-Filho M, Carvalho PCT, 1974. Resistência de cafeeiros à Pseudomonas garcae. In: Congresso Brasileiro de Pesquisas 2, Poços de Caldas. Rio de Janeiro, Brazil: IBC, 183.

Moschou PN, Sarris PF, Skandalis N et al., 2009. Engineered polyamine catabolism preinduces tolerance of tobacco to bacteria and oomycetes. Plant Physiology 149, 1970-81.

Mwangi IJ, Gichuru EK, Masanga J, Alakonya AE, 2018. A comparative analysis associated to virulence of Pseudomonas syringae pv. garcae, the causative agent of bacterial blight of coffee in Kenya. Journal of Scientific Agriculture 2, 76-84.

Nascimento R, Gouran H, Chakraborty S et al., 2016. The Type II secreted lipase/esterase LesA is a key virulence factor required for Xylella fastidiosa pathogenesis in grapevines. Scientific Reports 12, 18598.

Newman KL, Almeida RP, Purcell AH, Lindow SE, 2003. Use of a green fluorescent strain for analysis of Xylella fastidiosa colonization of Vitis vinifera. Applied and Environmental Microbiology 69, 7319-27.

Newman KL, Almeida RPP, Purcell AH, Lindow SE, 2004. Cell-cell signaling controls Xylella fastidiosa interactions with both insects and plants. Proceedings of the National Academy of Sciences of the United States of America 101, 1737-42.

Nguyen LC, Taguchi F, Tran QM et al., 2012. Type IV pilin is glycosylated in Pseudomonas syringae pv. tabaci 6605 and is required for surface motility and virulence. Molecular Plant Pathology 13, 764-74.

Nunes LR, Rosato YB, Muto NH et al., 2003. Microarray analyses of Xylella fastidiosa provide evidence of coordinated transcription control of laterally transferred elements. Genome Research 13, 570-8.

Nunney L, Yuan X, Bromley R et al., 2010. Population genomic analysis of a bacterial plant pathogen: novel insight into the origins of Pierce's disease of grapevine in the U.S. PLOS ONE 55, e15488.

Nunney L, Yuan X, Bromley RE, Stouthamer R, 2012. Detecting genetic introgression: high levels of intersubspecific recombination found in Xylella fastidiosa in Brazil. Applied and Environmental Microbiology 78, 4702-14.

Nunney L, Ortiz B, Russell SA et al., 2014. The complex biogeography of the plant pathogen Xylella fastidiosa: genetic evidence of introductions and subspecific introgression in Central America. PLoS ONE 9, e112463.

Ohshima M, Mitsuhara I, Okamoto M et al., 1999. Enhanced resistance to bacterial diseases of transgenic tobacco plants overexpressing sarcotoxin A, a bactericidal peptide of insect. Journal of Biochemistry $125,431-5$.

Okioga DM, 1977. Status of bacterial blight of coffee (elgon/solai; dieback) in Kenya. Kenya Coffee 42, 123-31.

Paradela Filho O, Sugimori MH, Ribeiro IJA et al., 1997. Constatação de Xylella fastidiosa em cafeeiro no Brasil. Summa Phytopathologica 23, 46-9.

Parkinson N, Bryant R, Bew J, Elphinstone J, 2011. Rapid phylogenetic identification of members of the Pseudomonas syringae species complex using the rpoD locus. Plant Pathology 60, 338-44.

Patrício FRA, Oliveira EG, 2014. Desafios no manejo de doeças do café. Visão Agrícola 12, 51-4.

Patrício FRA, Beriam LOS, Rossi A, Moraes A, Almeida IMG, 2010. Controle químico da mancha aureolada em uma região montanhosa. Tropical Plant Pathology 35, S119. 
Pauwelyn E, Huang C-J, Ongena M et al., 2013. New linear lipopeptides produced by Pseudomonas cichorii SF1-54 are involved in virulence, swarming motility, and biofilm formation. Molecular Plant-Microbe Interactions 26, 585-98.

Peng R, Zhang S, Wang S, 2003. The research progress on physiological race of Pseudomonas syringae pv. tabaci. Journal of the Yunnan Agricultural University 18, 198-202.

Pérez-Donoso AG, Sun Q, Roper MC et al., 2010. Cell wall-degrading enzymes enlarge the pore size of intervessel pit membranes in healthy and Xylella fastidiosa-infected grapevines. Plant Physiology 52, 1748-59.

Petek MR, Sera T, Alteia MZ et al., 2001. Resistência à bacteriose (Pseudomonas syringae pv. garcae) derivado do cruzamento entre 'IAPAR-59' e Coffea arabica Sh1 × 'Catuaí'. In: Simpósio de Recursos Genéticos para América Latina e Caribe. Londrina, Brazil: IAPAR L, $133-4$.

Petek MR, Sera T, Sera GH, Fonseca ICB, Shiguerito D, 2006. Seleção de progênies de Coffea arabica com resistência simultânea à mancha aureolada e à ferrugem alaranjada. Bragantia 65, 65-73.

Pooler MR, Hartung JS, 1995. Specific PCR detection and identification of Xylella fastidiosa strains causing citrus variegated chlorosis. Current Microbiology 31, 377-81.

Prado SS, Lopes JRS, Demétrio CGB, Borgatto AF, Almeida RPP, 2008. Host colonization differences between citrus and coffee isolates of Xylella fastidiosa in reciprocal inoculation. Scientia Agricola 65, 251-8.

Queiroz-Voltan RB, Cabral LP, Filho OP, 2004. Severidade do sintoma da bactéria Xylella fastidiosa em cultivares de cafeeiro. Bragantia 63, 395-404.

Queiroz-Voltan RB, Cabral LP, Filho OP, Fazuoli LC, 2006. Eficiência da poda em cafeeiros no controle da Xylella fastidiosa. Bragantia 65, 433-40.

Raaijmakers JM, de Bruijn I, de Kock MJD, 2006. Cyclic lipopeptide production by plant-associated Pseudomonas spp.: diversity, activity, biosynthesis, and regulation. Molecular Plant-Microbe Interactions 19, 699-710.

Raimundi MK, 2017. Identificação Bioquímica, Molecular e Patogenicidade de Isolados de Pseudomonas spp. Provenientes de Cafeeiros em Minas Gerais. Lavras, Brazil: Universidade Federal de Lavras, DSc thesis.

Ramkumar G, Lee SW, Weon H, Kim B, Lee YH, 2015. First report on the whole genome sequence of Pseudomonas cichorii strain JBC1 and comparison with other Pseudomonas species. Plant Pathology 64, 63-70.

Ramos AH, Shavdia LD, 1976. A die-back of coffee in Kenya. Plant Disease Reporter 60, 831-5.

Rapicavoli J, Ingel B, Blanco-Ulate B, Cantu D, Roper C, 2017. Xylella fastidiosa: an examination of a re-emerging plant pathogen. Molecular Plant Pathology 19, 786-800.

Robbs CF, Kimura O, Ribeiro RLD, Oyadomari LC, 1974. Bacterial leaf blight: a new disease of coffee (Coffea arabica L.) caused by Pseudomonas cichorii (Swingle) Stapp. Arquivos da Universidade Federal Rural do Rio de Janeiro 4, 1-5.

Rocha JG, Zambolim L, Maciel-Zambolim E, Vale FXR, 2010a. Temporal and spatial dynamics of coffee leaf scorch caused by Xylella fastidiosa. Australasian Plant Pathology 39, 234-40.

Rocha JG, Zambolim L, Zambolim EM, Vale FXR, Junior WCJ, Filho AB, 2010b. Quantification of yield loss due to coffee leaf scorch. Crop Protection 29, 1100-4.

Rodrigues Neto J, Figueiredo P, Mariotto PR, Robbs CF, 1981. Pseudomons andropogonis (Smith 1911) Stapp 1928, agente causal da 'mancha bacteriana escura' em folhas de cafeeiro (Coffea arabica L.). Instituto Biológico 48, 31-6.

Rodrigues Neto J, Silva CHD, Beriam LOS et al., 2006. Mancha bacteriana do cafeeiro causada por Pseudomonas syringae pv. tabaci. Summa Phytopathologica 32, 85.

Rodrigues LMR, Almeida IMG, Patrício FRA et al., 2013. Mancha Aureolada do Cafeeiro Causada por Pseudomonas syringae pv. garcae. Campinas, Brazil: Instituto Agronômico de Campinas.
Rodrigues LMR, Almeida IMG, Patrício FRA et al., 2017a. Aggressiveness of strains and inoculation methods for resistance assessment to bacterial halo blight on coffee seedlings. Journal of Phytopathology 165, 105-14.

Rodrigues LMR, Braghini MT, Filho OG, 2017b. SH1 leaf rust and bacterial halo blight coffee resistances are genetically independent. Bragantia 76, 209-13.

Rodrigues LMR, Sera GH, Filho OG, Beriam LOS, Almeida IMG, 2017c. First report of mixed infection by Pseudomonas syringae pathovars garcae and tabaci on coffee plantations. Bragantia 76, 543-9.

Roper MC, Greeve LC, Warren JG, Labavitch JM, Kirkpatrick BC, 2007. Xylella fastidiosa requires polygalacturonase for colonization and pathogenicity in Vitis vinifera grapevines. Molecular PlantMicrobe Interactions 20, 411-9.

Rose JL, 1989. Glycine max (L.) Merr. (soybean) cv. Manark. Australian Journal of Experimental Agriculture 29, 601.

Sánchez L, Zapata M, Rodríguez RP et al., 2003. Distribución y patogenicidad de Pseudomonas cichorii (Swingle) Stapp en el cultivo de café en Puerto Rico. Journal of Agriculture of the University of Puerto Rico 87, 123-35.

Saponari M, Boscia D, Nigro F, Martinelli GP, 2013. Identification of DNA sequences related to Xylella fastidiosa in oleander, almond and olive trees exhibiting leaf scorch symptoms in Apulia (southern Italy). Journal of Plant Pathology 95, 659-68.

Sarowar S, Kim YJ, Kim KD, Hwang BK, Ok SH, Shin JS, 2009. Overexpression of lipid transfer protein (LTP) genes enhances resistance to plant pathogens and LTP functions in long-distance systemic signaling in tobacco. Plant Cell Reports 28, 419-27.

Silva MRL, Meneguim AM, Paião FG, Meneguim L, Canteri MG, Leite RP Jr, 2007. Natural infectivity of Xylella fastidiosa Wells et al. in sharpshooters (Hemiptera: Cicadellidae) from coffee plantations of Paraná, Brazil. Neotropical Entomology 36, 274-81.

Smeeton BW, Ternouth RAF, 1992. Sources of resistance to powdery mildew, wildfire, angular spot, and Alternaria. CORESTA Information Bulletin 3, 127-35.

Smolka MB, Martins D, Winck FV, Santoro CE, Castellari RR, Ferrari F, 2003. Proteome analysis of the plant pathogen Xylella fastidiosa reveals major cellular and extracellular proteins and a peculiar codon bias distribution. Proteomics 3, 224-37.

Stavely JR, 1979. Disease resistance. In: Durbin RD, ed. Nicotiana: procedures for experimental use. USDA Technical Bulletin 1586, 87-110.

Studholme DJ, Gimenez-Ibanez S, MacLean D, Dangl JL, Chang JH, Rathjen JP, 2009. A draft genome sequence and functional screen reveals the repertoire of type III secreted proteins of Pseudomonas syringae pathovar tabaci 11528. BMC Genomics 10, 395.

Taguchi F, Ichinose Y, 2011. Role of type IV pili in virulence of Pseudomonas syringae pv. tabaci 6605: correlation of motility, multidrug resistance, and HR-inducing activity on a nonhost plant. Molecular Plant-Microbe Interactions 24, 1001-11.

Taguchi F, Ichinose Y, 2013. Virulence factor regulator (Vfr) controls virulence-associated phenotypes in Pseudomonas syringae pv. tabaci 6605 by a quorum sensing-independent mechanism. Molecular Plant Pathology 14, 279-92.

Taguchi F, Takeuchi K, Inagaki Y, Toyoda K, Shiraishi T, Ichinose Y, 2009. Glycosylation of flagellin from Pseudomonas syringae pv. tabaci 6605 contributes to evasion of host tobacco plant surveillance system. Physiological and Molecular Plant Pathology 74, 11-7.

Taguchi F, Suzuki T, Inagaki Y, Toyoda K, Shiraishi T, Ichinose Y, 2010. The siderophore pyoverdine of Pseudomonas syringae pv. tabaci 6605 is an intrinsic virulence factor in host tobacco infection. Journal of Bacteriology 192, 117-26.

Tanaka MAS, Ito MF, Dudienas C, Rodrigues Neto J, 1993. Pseudomonas syringae pv. tabaci on snap bean at Itababa region. Summa Phytopathologica 19, 31-4.

Tanaka M, Wali UM, Nakayashiki H et al., 2012. Implication of an aldehyde dehydrogenase gene and a phosphinothricin $\mathrm{N}$ acetyltransferase gene in the diversity of Pseudomonas cichorii virulence. Genes 3, 62-80. 
Tanassi DG, Bliska JB, Christie PJ, 2012. Surface organelles assembled by secretion systems of Gram-negative bacteria: diversity in structure and function. FEMS Microbiology Reviews 36, 1046-82.

Thakur S, Weir BS, Guttman DS, 2016. Phytopathogen genome announcement: draft genome sequences of 62 Pseudomonas syringae type and pathotype strains. Molecular Plant-Microbe Interactions 29, 243-6.

Valleau WD, Litton CC, Johnson EM, 1962. Susceptibility of wildfireresistant tobacco varieties to certain strains of Pseudomonas tabaci and P. angulata. Plant Disease Reporter 46, 36.

Van Sluys MA, Monteiro-Vitorello CB, Camargo LEA et al., 2002. Comparative genomic analysis of plant-associated bacteria. Annual Review of Phytopathology 40, 169-89.

Voegel TM, Warren JG, Matsumoto A, Igo MM, Kirkpatrick BC, 2010. Localization and characterization of Xylella fastidiosa haemagglutinin adhesins. Microbiology 156, 2172-9.

Wei CF, Kvitko BH, Shimizu R et al., 2007. A Pseudomonas syringae pv. tomato DC3000 mutant lacking the type III effector HopQ1-1 is able to cause disease in the model plant Nicotiana benthamiana. The Plant Journal 51, 32-46.

Wells JM, Raju BC, Hung HY, Weisburg WG, Mandelcopaul L, Brenner DJ, 1987. Xylella fastidiosa gen-nov. sp-nov. - Gram negative, xylem-limited, fastidious plant bacteria related to Xanthomonas spp. International Journal of Systematic Bacteriology 37, 136-43.

Woodend JJ, Mudzengerere E, 1992. Inheritance of resistance to wildfire and angular leaf spot derived from Nicotiana rustica var. Brasilea. Euphytica 64, 149-56.

Yorinori MA, Ribas AF, Ueno B, Massola Júnior NS, Leite RP Jr, 2003. Detecção de Xylella fastidiosa em germoplasma de cafeeiro. Fitopatologia Brasileira 28, 427-30.
Young JM, Triggs CM, 1994. Evaluation of determinative tests for pathovars of Pseudomonas syringae Van Hall 1902. Journal of Applied Bacteriology 77, 195-207.

Yu SM, Lee YH, 2012. First report of Pseudomonas cichorii associated with leaf spot on soybean in South Korea. Plant Disease 96, 142.

Yuan X, Morano L, Bromley R, Spring-Pearson S, Stouthamer R, Nunney L, 2010. Multilocus sequence typing of Xylella fastidiosa causing Pierce's disease and oleander leaf scorch in the United States. Phytopathology 100, 601-11.

Yun S, Lee JS, Do MS, Jeon YJ, Cha JY, Baik HS, 2015. Functional analysis of the aefR mutation and identification of its binding site in Pseudomonas syringae pv. tabaci 11528. Acta Biochimica et Biophysica Sinica 47, 938-45.

Zambolim L, Vale FXR, Pereira AA, Chaves GM, 1999. Manejo integrado das doenças do cafeeiro. In: Zambolim L, ed. Encontro sobre Produção de Café com Qualidade. Viçosa, Brazil: Universidade Federal de Viçosa, 134-215.

Zambolim L, Vale FXR, Zambolim EM, 2005. Doenças do cafeeiro (C. arabica e C. canephora). In: Kimati A, Amorim L, Rezende JAM, Bergamin Filho A, Camargo LEA, eds. Manual de Fitopatologia, vol. 2. São Paulo, Brazil: Agronômica Ceres, 165-80.

Zhu C, Wang Y, Li Y, Bhatti KH, Tian Y, Wu J, 2011. Overexpression of a cotton cyclophilin gene (GhCyp1) in transgenic tobacco plants confers dual tolerance to salt stress and Pseudomonas syringae pv. tabaci infection. Plant Physiology and Biochemistry 49, 1264-71.

Zoccoli DM, Takatsu A, Uesugi CH, 2011. Ocorrência de mancha aureolada em cafeeiros na região do Triângulo Mineiro e Alto Paranaíba. Bragantia 70, 843-9. 